\title{
Asbestos mortality: a Canadian export
}

$\mathrm{N}$ ext week, a handful of Canadian bureaucrats will fly to Rome for the 4th Conference of the Parties to the Rotterdam Convention, a treaty governing trade in substances that harm human health and the environment. Their mission? If past experience provides an accurate guide, they will be there, on behalf of the Government of Canada, to protect this country's asbestos industry, even if that means contributing to asbestos-related illnesses and deaths in the developing world.

That is a harsh indictment, but Canada is the only Western democracy to have consistently opposed international efforts to regulate the global trade in asbestos. ${ }^{1-3}$ And the government of Canada has done so with shameful political manipulation of science.

Years ago, Australia, Chile and the European Union proposed adding chrysotile (the predominant asbestos fibre used today) to the list of substances governed by the Rotterdam Convention. The convention requires the exporting government to notify the importing government before a dangerous substance is shipped in their direction, so that the importing government can exercise informed consent about whether to receive the substance. ${ }^{4}$ In essence, it is a regime of politeness. The convention does not ban trade in hazardous substances and need not take away even a gram from Canada's asbestos exports - unless, of course, an importing country's government, when asked for consent, thought better of it and said no.

You might think that Canada's government could have no possible objection to the convention and the polite rule of notice and informed consent. Yet you would be wrong. For several years, Canada has led a ferocious diplomatic opposition to listing chrysotile under the convention. Not a single Western democracy supports Canada's position, so Canada has made allies of a few less picky countries including Iran, Russia and Zimbabwe."

According to the Rotterdam Convention's review committee, which assesses substances before they are listed under the convention, "chrysotile is unequivocally a human carcinogen." ${ }^{\prime 6}$ The World Health Organization (WHO) and other international agencies agree. ${ }^{7-9}$ Even Canada's government acknowledges that "all forms of asbestos fibres, including chrysotile, are carcinogenic." ${ }^{5}$

However, Canada argues that "chrysotile is a less potent carcinogen ... and consequently poses a lower health risk." In an argument redolent of the tobacco industry's playbook on light cigarettes, Canada defends chrysotile on the basis that it is safer than other forms of asbestos.

But to say that chrysotile is safer is not to say it is safe. To be sure, chrysotile is chemically different than other forms of asbestos, called amphiboles. Exposure to amphibole asbestos causes notorious occupational and environmental illness and death: WHO estimates 100000 prevent- able deaths occur globally each year, mainly from mesothelioma and lung cancer. ${ }^{7}$ Whether the same diseases would result if asbestos was limited to pure chrysotile is endlessly debated.

Yet the debate is largely irrelevant. It is questionable whether "pure chrysotile" even exists: mines are not pristine environments and often contain mixed chrysotile and amphibole. Occupational exposure to chrysotile with even a trace amount of amphibole contamination $(0.002 \%-0.310 \%)$ is sufficient for amphibole to accumulate in the lungs over a lifetime. ${ }^{10}$ Disturbingly, Canada's government does not regularly monitor exported asbestos for amphibole contamination, so its claim to purvey a pure, safe product is made without evidence and is doubtful.

The fact that chrysotile can be contaminated with amphibole is an inconvenient truth that is often overlooked in industry-funded studies (see related News article, page 886). ${ }^{11}$ It is only by discounting the industry-funded publications that a clearer picture emerges. In studies of exposure to putatively pure chrysotile, there is a lesser, but still significant, rise in lung cancer and mesothelioma. ${ }^{12-15}$ In the latest meta-analysis, some chrysotile sources appear equally potent as amphibole in causing lung cancer. ${ }^{16,17}$ It is no wonder that WHO recommends that "the most efficient way to eliminate asbestosrelated diseases is to stop using all types of asbestos."

And stopping the use of asbestos is precisely what Canada is doing — but only in Canada.

In a practice that reeks of hypocrisy, Canada has limited the use of asbestos to prevent the exposure of Canadians to the danger, but it continues to be the world's second largest exporter of asbestos. ${ }^{18}$ Fully $96 \%$ of the asbestos that is produced in Canada is for export, primarily to developing countries such as India, Indonesia and Thailand, where it is mainly turned into asbestos cement for construction. ${ }^{5}$

Canada maintains that its export trade need not be dangerous, if the importing countries practise safe use and put "regulations, programs and practices equivalent to Canada's ... in place." This argument seems self-serving. Most developed countries, including Canada, have concluded that their occupational health and safety systems were no match for handling asbestos safely, and so they transitioned to using effective and affordable alternatives. ${ }^{19}$ For Canada to pretend that India, Thailand and Indonesia can succeed in managing asbestos safely, when developed countries have failed, is fanciful.

Canada is more than just a major asbestos exporter. To keep the export industry alive, it has become an avid asbestos cheerleader. Ottawa has poured more than \$19 million into the Chrysotile Institute, an advocacy group formerly called the Asbestos Institute before that name became unfashionable. ${ }^{5}$ Along with funds from the Government of Quebec, the institute is dedicated to promoting the 
safe-use canard and defending the beleaguered mineral from its critics.

Strangely, Canada's largesse runs out when it comes to helping developing countries deal with the decades-long aftermath of asbestos exposure. There are "no Government of Canada chrysotile asbestos programs that provide direct financial support to developing countries." ${ }^{\circ}$ It is subterranean ethics where Canada takes the wealth from asbestos exports, but abandons developing countries to their own devices to care for people made ill by asbestos or to institute alternatives to asbestos cement, which appear to be about $30 \%$ more expensive. ${ }^{20}$

A year ago, it appeared that Canada might rethink its position. Health Canada convened an international committee of scientific experts to study the risks of chrysotile exposure. The expert committee delivered its report in March, and Health Canada promised to publish it soon after. Yet as this issue goes to press, the report has been kept secret for over half a year, and sources tell CMAJ the blockage is in the prime minister's office. In contrast, the US Environmental Protection Agency has convened a similar expert group except that their process is transparent and the public is invited to attend the meetings. ${ }^{21}$ Small wonder that the chair of the Health Canada committee has since written to the government, lamenting that "Canada has a pretty bleak reputation in most of the health science world."”2

Sadly, the criticism is deserved. For Canada to export asbestos to poor countries that lack the capacity to use it safely is inexplicable. But to descend several steps further to suppress the results of an expert committee, pour millions of dollars into an institute that shills for the industry and oppose even the Rotterdam Convention's simple rule of politeness is inexcusable. Canada's government seems to have calculated that it is better for the country's asbestos industry to do business under the radar like arms traders, regardless of the deadly consequences. What clearer indication could there be that the government knows what it is doing is shameful and wrong?

Canada's government must put an end to this deathdealing charade. Canada must immediately drop its opposition to placing chrysotile under the Rotterdam Convention's notification and consent processes and stop funding the Chrysotile Institute. More importantly, Canada should do its part in alleviating the global epidemic of asbestos-related disease by ending the mining and export of chrysotile, as the WHO recommends.

\section{Amir Attaran LLB DPhil}

Canada Research Chair in Law, Population Health and Global Development Policy

University of Ottawa

Ottawa, Ont.

\section{David R. Boyd LLB}

Adjunct Professor, Resource and Environmental

Management

Simon Fraser University

Vancouver, BC

\section{Matthew B. Stanbrook MD PhD}

Deputy Editor, Scientific

CMAJ

Ottawa, Ont.

With the Editorial-Writing Team (Paul C. Hébert MD MHSc, Rajendra Kale MD, Barbara Sibbald BJ,

Ken Flegel MDCM MSc and Noni MacDonald MD MSc)

Competing interests: None declared for David Boyd. See www.cmaj.ca /misc/edboard.shtml for the Editorial-Writing Team's statements.

\section{REFERENCES}

1. Castleman BI, Joshi TK. The global asbestos struggle today. Eur J Oncol 2007;12: 149-54.

2. Brophy JT, Keith MM, Schieman J. Canada's asbestos legacy at home and abroad. Int J Occup Environ Health 2007;13:235-42.

3. Ladou J. The asbestos cancer epidemic. Environ Health Perspect 2004;112: 285-90.

4. Rotterdam Convention on the prior informed consent procedure for certain hazardous chemicals and pesticides in international trade. Norwich (UK): The Stationary Office; 2004. Available: www.pic.int/en/ConventionText/ONU-GB.pdf (accessed 2008 Sept 17).

5. Office of the Auditor General of Canada. Canada's policies on chrysotile asbestos exports [response by the Minister of Foreign Affairs to Environment Petition no. 179]. Ottawa (ON): The Office; 2006. Available: www.oag-bvg.gc.ca/internet /English/pet 179 e _28915.html (accessed 2008 Sept 22).

6. Secretariat for the Rotterdam Convention on the Prior Informed Consent Procedure for Certain Hazardous Chemicals and Pesticides in International Trade. Annex V: draft decision guidance document: chrysotile asbestos. Annex to document no: UNEP/FAO/RC/COP.3/11. Available: www.pic.int/home.php?type=b\&id=70 (accessed 2008 Sept 22)

7. World Health Organization. Elimination of asbestos-related disease. Geneva: The Organization; 2006. Available: http://whqlibdoc.who.int/hq/2006/WHO_SDE _OEH_06.03_eng.pdf (accessed 2008 Sept 17).

8. International Agency for Research on Cancer. Asbestos. IARC Monogr Eval Carcinog Risks Hum 1987;(Suppl 7):106-16.

9. International Labour Organization. 2006. Resolution concerning asbestos: adopted by the 95th session of the International Labour Conference, June 2006. (UNEP/FAO/RC/COP.3/INF/17). Available: www.pic.int/home.php?type=b\&id=70 (accessed 2008 Sept 22).

10. Tossavainen A, Kotilainen M, Takahashi K, et al. Amphibole fibres in Chinese chrysotile asbestos. Ann Occup Hyg 2001;45:145-52.

11. Pearce N. Corporate influences on epidemiology. Int J Epidemiol 2008;37:46-53.

12. Yano E, Wang ZM, Wang XR, et al. Cancer mortality among workers exposed to amphibole-free chrysotile asbestos. Am J Epidemiol 2001;154:538-43.

13. Mirabelli D, Calisti R, Barone AF, et al. Excess of mesotheliomas after exposure to chrysotile in Balangero, Italy. Occup Environ Med 2008; Jun 4. Epub ahead of print.

14. Hein MJ, Stayner LT, Lehman E, et al. Follow-up study of chrysotile textile workers: cohort mortality and exposure-response. Occup Environ Med 2007;64:616-25.

15. Li L, Sun TD, Zhang X, et al. Cohort studies on cancer mortality among workers exposed only to chrysotile asbestos: a meta-analysis. Biomed Environ Sci 2004; 17:459-68.

16. Berman DW, Crump KS. A. Meta-analysis of asbestos-related cancer risk that addresses fiber size and mineral type. Crit Rev Toxicol 2008;38:49-73.

17. Berman DW, Crump KS. Update of potency factors for asbestos-related lung cancer and mesothelioma. Crit Rev Toxicol 2008;38:1-47.

18. Canada Minerals Yearbook 2006. Chrysotile. Ottawa (ON): Natural Resources Canada. Minerals and Metals Sector; 2007. Available: www.nrcan.gc.ca/mms/cmy /content/2006/20.pdf (accessed 2008 Sept 17).

19. Virta RL. Asbestos substitutes. In: Kogel JE, Nikhil C, Trivedi JM, et al., editors. Industrial minerals and rocks: commodities, markets and uses. 7th ed. Littleton (CO): Society for Mining, Metallurgy and Exploration; 2006.

20. Tri DD, Toan NN, Cong NT. Possibility of using substitute materials for asbestos and non-asbestos fibro cement roofing tiles to reduce environmental pollution and increase workers' health protection in Vietnam. Proceedings [CD-ROM] of the Global Asbestos Conference; 2004 Nov 19-21; Tokyo, Japan. Tokyo, Japan: World Asbestos Congress; 2004. Available: http://worldasbestosreport.org/gac2004/pl_7_04_e.pdf (accessed 2008 Aug 22)

21. Federal Register/ Vol 73, No 108/ Wednesday, June 4, 2008/Notices. US Environmental Protection Agency. Science advisory board staff office: notification of an upcoming meeting of the science advisory board asbestos committee. Washington: The Register; 2008. Available: www.epa.gov/fedrgstr/EPA-MEETINGS /2008/June/Day-04/m12503.pdf (accessed 2008 Sept 22).

22. Daubs K. Asbestos report 'misused:' scientists. Ottawa Citizen 2008 May 28. Available: www.canada.com/ottawacitizen/news/story.html?id=4c342ebe-26334ea4-bc06-34797b8ed932 (accessed 2008 Sept 17). 